\title{
A Further Study of Seminal Plasma: Lactate Dehydrogenase and Lactate Dehydrogenase-X Activities and Diluted Semen Absorbance $\left.{ }^{1}\right),{ }^{2}$ )
}

\author{
Sabahattin Aydın ${ }^{1}$, Yüksel Yılmaz ${ }^{1}$ Öner Odabaș ${ }^{1}$, Ramazan Șekeroğlu ${ }^{2}$, Mehmet Tarakçioğlu ${ }^{2}$ and \\ Mustafa K. Atilla ${ }^{1}$ \\ ${ }^{1}$ Department of Urology, School of Medicine, Yüzüncü Yıl University, Van, Turkey \\ 2 Department of Biochemistry, School of Medicine, Yüzüncü Yll University, Van, Turkey
}

Summary: Activities of total lactate dehydrogenase, which plays an important role in providing energy for cell metabolism, lactate dehydrogenase- $\mathrm{X}$, an isoenzyme of lactate dehydrogenase supposed to be specific for germinal epithelium activity, diluted semen absorbance and some other properties have been measured in 51 seminal plasma samples. Aiming to study its clinical use as a marker of seminiferous epithelium activity, determination of isoenzyme-X and investigation of correlation between it and the spermiogram properties were carried out. Besides lactate dehydrogenase and lactate dehydrogenase- $X$ activity, their ratio and diluted semen absorbance were correlated with the different properties of the spermiogram, the best correlation of the enzymes being obtained with the total sperm count and motile sperm count. Correlation of diluted semen absorbance with the total sperm count and motile sperm count was also noted, whereas it did not correlate with sperm concentration and motility rate. The data suggests the clinical utility of these properties as reliable markers for both germinal activity and spermatozoid quality when "total sperm count" and "motile sperm count" are used to define sperm properties instead of just sperm concentration and motility rate.

\section{Introduction}

The idea that abnormality in the biochemical composition and physical properties of seminal plasma might indicate male infertility drew more interest to the research of the constituents of seminal plasma (1). Enzyme studies show that lactate dehydrogenase exhibits high activity (2). An attempt to study the biochemical, physical and functional properties of semen to evidence markers of diseases concerning fertility would be of some help to establish the diagnosis more easily.

In this paper we determined diluted semen absorbance, activities of total lactate dehydrogenase, which plays an important role in providing energy for cell metabolism and lactate dehydrogenase- $X$, an isoenzyme of lactate dehydrogenase supposed to be specific for germinal epithelium activity in the seminal plasma of infertile subjects. Lactate dehydrogenase ${ }^{3}$ ) is a hydrogen transfer enzyme that catalyses the oxidation of $L$-lactate to pyruvate with the mediation of $\mathrm{NAD}^{+}$as hydrogen acceptor.

1) The work was carried out in:

Yüzüncü Yıl Üniversitesi Tıp Fakültesi Biyokimya Laboratuvarı

2) Presented at the 8th International Andrological Symposium 17-

20 April 1996 in North Cyprus

3) Enzymes

$L$-lactate : $\mathrm{NAD}^{+}$oxidoreductase, EC 1.1.1.27

Lactate dehydrogenase- $\mathrm{X}$ or lactate dehydrogenase-C: isoenzymes $\mathrm{X}$ and $\mathrm{C}$
The reaction is reversible and the reaction equilibrium strongly favors the reverse reaction, namely the reduction of pyruvate to lactate (3). The total serum lactate dehydrogenase can be separated into 5 fractions, their electrophoretic pattern is used to differentiate diseases of the various body systems. The subunit composition of the 5 isoenzymes, in order of decreasing anodal mobility in an alkaline medium are LDH-1, LDH-2, LDH-3, LDH-4 and LDH-5. A different sixth lactate dehydrogenase isoenzyme (LDH-X, also called LDH-C, composed of $4 \mathrm{X}$ (or C) subunits) is present in postpubertal human testis (3). With the purpose of studying their clinical use as markers of semen quality, their correlation with the spermiogram properties were investigated.

\section{Materials and Methods}

A total of 51 semen samples were classified into the three groups:

1) normozoospermic patients (sperm concentration $>15 \times 10^{3} / 1$ ) $(\mathrm{n}=30)$;

2) oligozoospermic patients (sperm concentration $<15 \times 10^{3} / 1$ ) $(n=11)$;

3) azoospermic patients $(n=10)$.

All samples were collected in our laboratory by masturbation after 3 to 4 days of sexual abstincence. They were examined after liquefaction at $37^{\circ} \mathrm{C}$. Routine examination of the semen specimen was performed by the same technician. Ejaculate volume, sperm concentration, and sperm motility were determined. Seminal plasma was obtained by centrifugation for 20 minutes at $1000 \mathrm{~g}$. Total lactate dehydrogenase activity was determined in an analyser (Techni- 
con RA-XT) using a commercial kit (Merck - Biotrol) which uses the pyruvate to lactate method. Lactate dehydrogenase isoenzymes were separated by gel elektrophoresis (in Helena Laboratories). The gels were scanned with a CliniScan 2 densitometer at $595 \mathrm{~nm}$ in which the relative percentage of lactate dehydrogenase- $X$ was obtained. The activity of the isoenzyme lactate dehydrogenase- $X$ was calculated from its ratio to total lactate dehydrogenase.

Semen sample $(0.5 \mathrm{ml})$ was mixed with $9.5 \mathrm{ml}$ distilled water. The diluted semen absorbance of the obtained $1 / 20$ semen sample was scanned with the Pharmacia-Biotech Novaspec II (serial No: 01118) spectrophotometer at $500 \mathrm{~nm}$.

Pearson's correlation analysis, one-way ANOVA variance analysis and Post Hoc Newman-Keuls multiple comparison tests were used for statistical analysis. The sensitivity, specificity and predictive values for lactate dehydrogenase- $\mathrm{X}$ were calculated as described by Altman and Bland $(4,5)$.

\section{Results}

Characteristics of classified donor semen samples and total lactate dehydrogenase activity, lactate dehydrogenase-X activity, their ratio and diluted semen absorbance measurements of the three groups are shown in table 1. The difference of lactate dehydrogenase between normospermic, oligospermic and azoospermic groups was not statistically significant $(\mathrm{F}=1.09, \mathrm{DF}=2.48$, $\mathrm{p}=0.344)$.

Lactate dehydrogenase- $X$ activity in normospermic group was significantly different than it is in the other two groups $(p=0.035)$. The difference of $\%$ lactate dehydrogenase- $X$

$$
\frac{\mathrm{LDH}-\mathrm{X}}{\text { total LDH }} \times 100
$$

was found highly significant in all of the groups $(\mathrm{p}<0.01)$. Cut-off point for $\%$ lactate dehydrogenase for normospermia was estimated as $27 \%$. Thus, the sensitivity, specificity, positive predictive value and negative predictive value for lactate dehydrogenase- $\mathrm{X}$ were $73 \%, 80 \%, 85 \%$ and $68 \%$ respectively. Diluted semen absorbance did not significantly differ between these groups $(F=0.07, D F=2.48, p=0.930)$.
Tables 2, 3 and 4 summarize the relationship between the studied seminal properties of all samples, normospermic and oligospermic samples respectively. Some significant correlation was obtained between sperm concentration and enzyme activities in table 2 using unclassified samples (lactate dehydrogenase, $\mathrm{p}=0.025$, lactate dehydrogenase-X, $\mathrm{p}=0.008, \%$ lactate dehydrogenase- $X, p=0.015$ ), this was not so in case of oligospermia $(p>0.05)$. We found a close relationship between total sperm count and lactate dehydrogenase or lactate dehydrogenase- $X(p<0.05)$ in all groups. Motility percent does not seem to be related with any other parameters. Like the enzymes, diluted semen absorbance does not always correlate with sperm concentration and motility, but a very good correlation was obtained between diluted semen absorbance and total sperm count (in unclassified and normospermic groups $\mathrm{p}<0.001$; in oligospermic group $\mathrm{p}=0.01$ ).

\section{Discussion}

Lactate dehydrogenase plays an important role in providing energy for cell metabolism and is present in most cells and biologic fluids. Lactate dehydrogenase- $\mathrm{X}$ is an isoenzyme of lactate dehydrogenase found in human postpubertal testis (6) and is supposed to be specific for germinal epithelium activity (7).

Although the difference of lactate dehydrogenase level in normospermic, oligospermic and azoospermic semen did not show statistical significance, lactate dehydrogenase- $X$ was significantly higher only in normospermic semen. As stated by Buonaguidi et al. (8), the existence of this isoenzyme is closely associated with active spermatogenesis. On the other hand, \% lactate dehydrogenase-X was found significantly different in all groups. This fact suggests that \% lactate dehydrogenase- $\mathrm{X}$ is a more reliable predictor of semen quality than lactate dehydrogenase- $X$ itself. The higher contribution of testicular isoenzyme (lactate dehydrogenase-X) in the total lac-

Tab. 1 Spermiogram findings, semen lactate dehydrogenase, isoenzyme values and the diluted semen absorbance of the normo-, oligo- and azoospermic patients.

\begin{tabular}{lccc}
\hline & $\begin{array}{l}\text { Normospermia } \\
\mathrm{n}=30\end{array}$ & $\begin{array}{l}\text { Oligospermia } \\
\mathrm{n}=11\end{array}$ & $\begin{array}{l}\text { Azoospermia } \\
\mathrm{n}=10\end{array}$ \\
\hline Sperm concentration, $10^{9} / 1$ & $40.57 \pm 23.94$ & $3.56 \pm 3.05$ & - \\
Sperm count, $10^{6}$ & $101.28 \pm 64.09$ & $37.32 \pm 49.50$ & - \\
\% Motility & $69.50 \pm 16.15$ & $22.27 \pm 26.96$ & - \\
Motile sperm count, 10 & $70.29 \pm 47.86$ & $19.55 \pm 28.29$ & - \\
Lactate dehydrogenase, kU/1 & $2853.73 \pm 1922$ & $2330.91 \pm 2190$ & $1866 \pm 1494$ \\
Lactate dehydrogenase-X, kU/1 & $941.07 \pm 669.89^{\mathrm{a}}$ & $664.27 \pm 758.76$ & $340.5 \pm 144.04$ \\
\% Lactate dehydrogenase-X & $32.66 \pm 6.19^{\mathrm{b}}$ & $25.96 \pm 7.21^{\mathrm{b}}$ & $20.65 \pm 5.39^{\mathrm{b}}$ \\
Diluted semen absorbance & $0.214 \pm 0.24$ & $0.222 \pm 0.31$ & $0.2509 \pm 0.28$ \\
\hline
\end{tabular}


Tab. 2 Table of correlations in the unclassified samples.

\begin{tabular}{lllll}
\hline & $\begin{array}{l}\text { Lactate } \\
\text { dehydrogenase } \\
\mathrm{kU} / 1\end{array}$ & $\begin{array}{l}\text { Lactate } \\
\text { dehydrogenase-X } \\
\mathrm{kU} / 1\end{array}$ & $\begin{array}{l}\text { \% Lactate } \\
\text { dehydrogenase-X }\end{array}$ & $\begin{array}{l}\text { Diluted } \\
\text { semen } \\
\text { absorbance }\end{array}$ \\
\hline Sperm concentration & $0.3506^{\mathrm{a}}$ & $0.4114^{\mathrm{a}}$ & $0.3790^{\mathrm{a}}$ & 0.2256 \\
Total sperm count & $0.4656^{\mathrm{a}}$ & $0.5161^{\mathrm{a}}$ & $0.4105^{\mathrm{a}}$ & $0.5132^{\mathrm{a}}$ \\
\% Motility & 0.1767 & 0.2487 & $0.5637^{\mathrm{b}}$ & 0.2865 \\
Total motile sperm count & $0.3723^{\mathrm{a}}$ & $0.4146^{\mathrm{a}}$ & $0.4264^{\mathrm{a}}$ & $0.5264^{\mathrm{b}}$ \\
\hline
\end{tabular}

${ }^{\mathrm{a}} \mathrm{p}<0.05,{ }^{\mathrm{b}} \mathrm{p}<0.001$

Tab. 3 Table of correlations in normospermic samples.

\begin{tabular}{lllll}
\hline & $\begin{array}{l}\text { Lactate } \\
\text { dehydrogenase } \\
\mathrm{kU} / 1\end{array}$ & $\begin{array}{l}\text { Lactate } \\
\text { dehydrogenase-X } \\
\mathrm{kU} / 1\end{array}$ & $\begin{array}{l}\text { \% Lactate } \\
\text { dehydrogenase-X }\end{array}$ & $\begin{array}{l}\text { Diluted } \\
\text { semen } \\
\text { absorbance }\end{array}$ \\
\hline $\begin{array}{l}\text { Sperm concentration } \\
\text { Total sperm count }\end{array}$ & $0.4315^{\mathrm{a}}$ & $0.4773^{\mathrm{a}}$ & 0.2169 & $0.3902^{\mathrm{a}}$ \\
\% Motility & $0.3711^{\mathrm{a}}$ & $0.3974^{\mathrm{a}}$ & 0.1978 & $0.5837^{\mathrm{a}}$ \\
Total motile sperm count & -0.1110 & -0.0543 & 0.2867 & 0.2049 \\
\hline
\end{tabular}

${ }^{\mathrm{a}} \mathrm{p}<0.05,{ }^{\mathrm{b}} \mathrm{p}<0.001$

Tab. 4 Table of correlations in oligospermic samples.

\begin{tabular}{lllcc}
\hline & $\begin{array}{l}\text { Lactate } \\
\text { dehydrogenase } \\
\mathrm{kU} / 1\end{array}$ & $\begin{array}{l}\text { Lactate } \\
\text { dehydrogenase-X } \\
\mathrm{kU} / 1\end{array}$ & $\begin{array}{l}\text { \% Lactate } \\
\text { dehydrogenase-X }\end{array}$ & $\begin{array}{l}\text { Diluted } \\
\text { semen } \\
\text { absorbance }\end{array}$ \\
\hline Sperm concentration & 0.0125 & -0.1180 & -0.5008 & -0.2000 \\
Total sperm count & $0.7923^{*}$ & $0.8453^{*}$ & 0.5528 & $0.6082^{*}$ \\
\% Motility & 0.5125 & 0.5383 & $0.6057^{*}$ & $0.7758^{*}$ \\
Total motile sperm count & $0.7192^{*}$ & $0.7687^{*}$ & $0.6081^{*}$ & $0.7339^{*}$ \\
\hline
\end{tabular}

$* \mathrm{p}<0.05$

tate dehydrogenase would suggest higher seminiferous epithelial activity.

Although there seems to be a correlation between sperm concentration and enzyme activities in table 2 $(p=0.05)$, this correlation disappears in the case of oligospermia $(p>0.05)$, as seen in table 4 . Total sperm count shows a correlation with lactate dehydrogenase and lactate dehydrogenase- $\mathrm{X}$ regardless of the group to which it belongs, suggesting that it might be a more reliable spermiogram property than sperm concentrations. As also reported by others $(9,10,11)$, we found a high correlation between seminal lactate dehydrogenase$X$ activity ( $r=0.7237)$ and the total sperm count, while no correlation had been reported between sperm motility, viability and morphology. On the other hand, diluted semen absorbance does not always correlate with sperm concentration and motility, whereas there is always correlation between diluted semen absorbance and total sperm count which supports our idea.

Lactate dehydrogenase- $\mathrm{X}$ seemed to correlate with various sperm properties when all of the samples were basically considered, but this correlation did not always persist when samples were grouped as normospermic or oligospermic. Thus, correlation studies of any seminal ingredients with spermiogram properties without grouping the samples would not be reliable, because the correlation might not be present when upper and lower variables of the spermiogram were considered. The degree of the correlation of lactate dehydrogenase-X with sperm count indicates its significance in representing the quantity of spermatozoa rather than the quality. Noguera et al. (11) also reported the best correlation with the sperm count. Their logistic regression analysis gave a mathematical model that included viability and percent lactate dehydrogenase-X. The significant low activity of lactate dehydrogenase- $X$ in azoospermia suggests poor germinal activity in secretory azoospermia. Apparently no lactate dehydrogenase- $X$ activity would be expected in excretory azoospermia (obstructive azoospermia), enabling us to avoid testicular biopsy in some cases (11).

The data suggests that the enzyme does not correlate with motility, but a high degree correlation does exist between motile sperm count and diluted semen absorbance; this represents the only marker of the study that predicts quality rather than quantity. Thus, it would be wise to use motile sperm count rather than motility rate 
or $\%$ motility. This was probably the opinion of the authors $(12,13)$ who limited its priority in the differential diagnosis of obstructive and non-obstructive azoospermia. According to these authors, the alterations of diluted semen absorbance were related to the secretion of a protein-like substance into the seminal plasma somewhere in the genital tract such as $\alpha$-glycosidase, epidermal growth factor, sperm coating proteins, seminogelin, prostate acid phosphatase, prostate-specific antigen, and $\beta$-microseminoprotein (12), or mediated directly by spermatozoa (13).

\section{References}

1. Comhaire FH, Dekrester D, Farley TMM, Rove PJ. Towards more objectivity in diagnosis and management of male infertility. Int J Androl 1987; 5:5-8.

2. Jeyalectumie C, Subramoniam T. Biochemistry of seminal secretions of the crab Scylla Serrata with reference to sperm metabolism and storage in the female. Mol Reprod Dev 1991; 30:44-45.

3. Mass DW, Henderson AR. Enzymes. In: Bultis CA, Aswood ER, editors. Clinical chemistry. Philadelphia: Saunders, 1994;735-896.

4. Altman DG, Bland JM. Diagnostic tests 1: sensitivity and specificity. Br Med J 1994; 308:1552.

5. Altman DG, Bland JM. Diagnostic tests 2: predictive values. Br Med J 1994; 309:102.

6. Blanco A. On the functional significance of LDHX. Johns Hopkins Med J 1980; 146:231-5.

7. Hintz M, Goldberg E. Immunohistochemical localization of LDH-X during spermatogenesis in mouse testes. Dev Biol $1977 ; 57: 375-84$.

8. Buonaguidi A, Grasso M, Lania C, Castelli M, Francesca F, Rigatti P. Experience with the determination of LDH-X in seminal plasma as diagnostic and prognostic factor in varicocele. Arch Exp Urol 1993; 46:35-9.

9. Orlando C, Casano R, Caldini AL, Forti G, Barni T, Bonfanti $\mathrm{L}$, et al. Measurement of seminal LDH-X and transferrin in normal and infertile men. J Androl 1988; 9:220-3.

10. Uchijima Y, Yoshida K, Saito H. A further study of human seminal plasma lactate dehydrogenase-C4: kinetic properties of LDH-C4. Hinyokika, Kiyo 1989; 35:457-63.
Similar to the previous studies (14-17), our results supported the clinical utility of the testis specific isoenzyme, lactate dehydrogenase- $X$ as a reliable index for germinal activity. On the other hand, besides its role in differential diagnosis of obstructive or non-obstructive azoospermia diluted semen absorbance may be used as a tracer of total sperm count and motile sperm count. The utility of including lactate dehydrogenase- $X$ activity and diluted semen absorbance determinations as a routine with the spermiogram could be suggested.

11. Noguera Valesco JA, Tovar Zapata I, Martinez Hernandez P, Perez Albacete M, Tortosa Oltra J, Parrilla Paricio JJ. Lactic dehydrogenase-C4 activity in seminal plasma and male infertility. Fertil Steril 1993; 60:331-5.

12. Tunçbilek E, Aydoğanlı L, Çevik C, Baykam M. Cengiz T, Akalın Z. Normospermik, oligospermik ve azospermik donör gruplarında sperm sayıs ile dlue semen absorbans (DS) testi arasındaki ilișk ve DSA'nın obstrüktif azospermi tanısindaki yeri. Türkiye Tıp Dergisi 1996; 2:99-109.

13. Çevik C. Sperm analizi ile tubuler tıkanıklığın yerinin tayini. Vakıf Gureba Hastanesi Dergisi 1988; 15:146-8.

14. Virgi N. LDH-C4 in human seminal plasma and its relationship to testicular function I: methodological aspects. Int J Androl 1985; 8:193-200.

15. Eliasson R, Virji N. LDH-C4 in human seminal plasma and its relationship to testicular function II: clinical aspects. Int $\mathrm{J}$ Androl 1985; 8:201-4.

16. Gavella M, Cvitkovic P, Skrabalo Z. Seminal plasma isoenzyme LDH-X in infertile men. Arch Androl 1982; 14:104-9.

17. Gavella M, Cvitkovic P, Papic Z, Skrabalo Z. Seminal plasma isoenzyme LDH-X in testosterone rebound therapy. Arch Androl 1987; 19:65-9.

\section{Received May 27, 1996/January 17, 1997}

Corresponding author: Dr. Sabahattin Aydin, Tıp Fakültesi, Üroloji ABD, Yüzüncü Yll Üniversitesi, Maraș Caddesi, 65300 Van, Turkey 